\title{
ANALISIS PENGARUH KINERJA KEUANGAN DAN GOOD CORPORATE GOVERNANCE TERHADAP FINANCIAL DISTRESS (STUDI KASUS PADA PERUSAHAAN PERBANKAN DI BEI TAHUN (2016-2018)
}

\author{
Anggita Julia Mahmud \\ anggitajuliyamahmud@gmail.com \\ Jurusan Akuntansi Fakultas Ekonomi dan Bisnis Universitas Mataram \\ Lilik Handajani \\ lilikhandajani@unram.ac.id \\ Jurusan Akuntansi Fakultas Ekonomi dan Bisnis Universitas Mataram \\ Iman Waskito \\ waskitoiman@unram.ac.id \\ Jurusan Akuntansi Fakultas Ekonomi dan Bisnis Universitas Mataram
}

\begin{abstract}
ABSTRAK
Tujuan dalam penelitian ini adalah untuk menganalisa pengaruh kinerja keuangan dan good corporate governance terhadap financial distress pada perusahaan perbankan yang terdaftar di BEI pada tahun 20162018.Populasi dalam penelitian ini adalah perusahaan perbankan konvensional yang terdaftar di Bursa Efek Indonesia (BEI) periode 2016-2018. Sampel yang diambil dalam penelitian ini adalah 41 perusahaan perbankan konvensional. Analisis data dalam penelitian ini menggunakan metode analisis regresi berganda.Hasil penelitian ini membuktikan bahwa non perfoming loan dan good corporate governance berpengaruh negatif signifikan terhadap financial distress sedangkan loan to deposit ratio, return on asset, dan capital adequacy ratio berpengaruh positif signifikan terhadap financial distress yang diproksikan dengan altman z-score.
\end{abstract}

Kata Kunci: kinerja keuangan, good corporate governance, financial distress, dan altman z-score

ABSTRACT

The purpose of this study was to analyze the effect of financial performance and good corporate governance on the financial distress of banking companies listed on the IDX in the 2016-2018 period. The population in this study are conventional banking companies listed on the IDX for the period 2016-2018. The sample taken in this study was 41 conventional banking companies. Data analysis in this study used the method of regression analysis. The results of this study prove that non perfoming loan and good corporate governance have a significant negative effect on the financial distress while the loan to deposit ratio, return on assets, and capital adequacy ratio have a significant positive effect on the financial distress, which is proxied by the Altman zscore.

Keywords: Financial Performance, Good Corporate Governance, Financial Distress, and Altman Z-Score

\section{PENDAHULUAN}

Kebangkrutan merupakan masalah yang harus diwaspadai oleh perusahaan. Kebangkrutan biasanya diartikan sebagai kegagalan perusahaan dalam menjalankan operasi perusahaan untuk menghasilkan laba (Supardi, 2003). Apabila suatu perusahaan telah bangkrut berarti perusahaan tersebut benar-benar mengalami kegagalan usaha, sehingga bagi beberapa perusahaan yang mengalami masalah keuangan ini mencoba untuk mengatasi masalahnya tersebut dengan cara melakukan pinjaman atau penggabungan usaha. Namun, juga terdapat perusahaan yang mengambil alternatif lain seperti menutup atau menghentikan usahanya. Oleh karena itu, penting bagi perusahaan untuk sedini mungkin menganalisis tanda-tanda awal dari kebangkrutan sehingga pihak manajemen dapat melakukan perbaikan, dan pihak investor pun dapat melakukan persiapan untuk menghadapi kemungkinan yang akan terjadi (Sastriana, 2013). 
Perbankan dalam kehidupan suatu negara mempunyai peranan penting untuk memajukan perekonomian negara dan menjadi salah satu agen pembangunan (agen of development). Namun, bank memiliki banyak resiko terutama resiko keuangan. Oleh karena itu perlu diantisipasi dengan model untuk memprediksi financial distress. Jika kondisinya sudah diketahui sejak awal, maka upaya harus dilakukan sebanyak mungkin agar bank tidak mengalami kebangkrutan. Kecuali jika tidak diantisipasi, beberapa bank harus dilikuidasi, direstrukturisasi dan bahkan ditutup dengan kebijakan Bank Indonesia yang berlaku (Africa, 2018).

Salah satu yang dapat dijadikan sebagai alat ukur untuk memprediksi terjadinya financial distress yaitu dengan melakukan pengukuran kinerja keuangan yang terdapat dalam laporan keuangan yang telah disusun secara akurat. Dengan adanya kinerja keuangan yang baik maka kemungkinan terjadinya financial distress akan semakin kecil. Kinerja keuangan perusahaan dapat diukur dengan menggunakan rasio keuangan. Rasio keuangan merupakan angka yang diperoleh dari hasil perbandingan antara satu pos laporan keuangan dengan pos lainnya yang mempunyai hubungan yang relevan dan signifikan. Rasio keuangan dapat digunakan untuk mengevaluasi kondisi keuangan perusahaan dan kinerjanya (Wongsosudono dan Chrissa, 2013).

Elloumi dan Gueyie (2001) berpendapat bahwa kegagalan perusahaan di berbagai belahan dunia dalam usahanya untuk bertahan tidak hanya disebabkan oleh aspek finansial namun juga seringkali dikaitkan dengan aspek non-finansial, misalnya kelemahan penerapan struktur corporate governance. Aspek tata kelola atau GCG juga merupakan faktor yang sangat penting untuk melihat apakah bank tersebut sudah dikelola dengan baik sesuai dengan aturan-aturan yang ada atau belum.

Berdasarkan uraian beberapa peneliti terdahulu terdapat beberapa rasio kinerja keuangan dan good corporate governance yang akan diteliti kembali karena penelitian sebelumnya menunjukkan adanya hasil yang tidak konsisten atau berbeda. Sehingga, perbedaan ini membuat peneliti tertarik untuk meneliti lebih lanjut kebaruan informasi terhadap variabelvariabel yang diteliti pada periode 2016-2018 pada perusahaan perbankan yang terdaftar di BEI.

\section{TINJAUAN LITERATUR}

\section{Teori Sinyal (Signaling Theory)}

Teori sinyal pertama kali dikemukakan oleh Spence pada tahun 1973. Sinyal diartikan sebagai isyarat yang dilakukan oleh perusahaan (manajer) kepada pihak luar (investor). Segala bentuk atau jenis dari sinyal yang dikeluarkan oleh perushaan, dimaksudkan untuk menyiratkan sesuatu dengan harapan pasar atau pihak eksternal akan melakukan perubahan penilaian atas perusahaan (Gumanti, 2009). Sebelum berinvestasi investor akan melakukan analisa fundamental terhadap suatu perusahaan seperti menganalisis rasio-rasio keuangan. Hal ini dikarenakan informasi dalam laporan keuangan suatu perusahaan diyakini memberikan gambaran tentang kondisi perusahaan saat ini sekaligus dapat memprediksi kondisi perusahaan di masa yang akan datang (Uli, 2009).

\section{Bank}




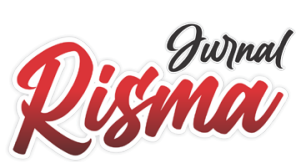

Vol. 1 No. 4 Desember 2021

gerakan national development dengan tujuan menaikkan pemerataan, kenaikan ekonomi, dan keseimbangan nasional menuju pertumbuhan kesejahteraan rakyat banyak.

\section{Financial Distress}

Kesulitan keuangan bisa diartikan sebagai kegagalan dalam menutupi biaya operasi perusahaan, tingkat laba lebih kecil dari pengeluaran, proyeksi tidak terpenuhi, gagal dalam memenuhi kewajiban, kekayaan bersih yang negative, dan lain-lain yang dapat menyebabkan perusahaan bangkrut. Sebuah perusahaan dikatakan mengalami kondisi financial distress yaitu pada saat perusahaan tersebut tidak mempunyai kemampuan untuk memenuhi jadwal pembayaran kembali hutangnya kepada kreditur pada saat jatuh tempo.

\section{Kinerja Keuangan}

Kinerja keuangan adalah suatu ukuran yang digunakan untuk melihat sejauh mana prestasi kerja yang telah dicapai oleh suatu perusahaan. Pengukuran kinerja keuangan dapat dilakukan dengan melakukan analisis rasio keuangan yang terdapat dalam laporan keuangan yang telah disusun secara lengkap. Informasi yang terdapat dalam laporan keuangan digunakan sebagai bentuk komunikasi yang dilakukan oleh pihak perusahaan kepada berbagai pihak yang memiliki kepentingan terhadap informasi tersebut. Hal ini dikarenakan laporan keuangan dapat menggambarkan data keuangan dan berbagai aktivitas perusahaan. Laporan keuangan akan menjadi informasi yang lebih berguna apabila angka-angka tersebut saling dibandingkan dalam bentuk rasio keuangan (Hery, 2015).

\section{Good Corporate Governance}

Good Corporate Governance Perbankan adalah suatu tata kelola bank yang menerapkan prinsip keterbukaan (transparency), akuntabilitas (accountability), pertanggungjawaban (responsibility), independensi (independency), dan kewajaran (fairness).

\section{Penerapan Tata Kelola}

Perbankan mewajibkan bank untuk melakukan penilaian sendiri (self assessment) atas penerapan Tata Kelola Bank yang mencakup 11 aspek penilaian. Hasil penilaian self assessment oleh pihak manajemen bank yang dilakukan dengan pembobotan kemudian akan diberikan peringkat penilaian. Penetapan peringkat faktor good corporate governance dikategorikan dalam 5 (lima) peringkat yakni peringkat 1, peringkat 2, peringkat 3, peringkat 4 , dan peringkat 5 .

\section{Pengembangan Hipotesis}

\section{Pengaruh Non Performing Loan terhadap Financial Distress}

Non Performing Loan (NPL) merupakan rasio manajemen bank dalam mengelola kredit bermasalah dan keseluruhan kredit yang diberikan bank terhadap kreditur (nasabah). Rasio ini menggambarkan kualitas dari aset kredit yang kredibilitasnya digolongkan menjadi kurang lancar, diragukan, dan macet. NPL digunakan untuk mengukur kemampuan bank dalam mengkover risiko-risiko kegagalan pengembalian kredit oleh kreditur.

$\mathrm{H}_{1}$ : Non Perfoming Loan (NPL) berpengaruh terhadap financial distress perusahaan perbankan

\section{Pengaruh Loan to Deposit Ratio terhadap Financial Distress}

Loan Deposit Ratio menyatakan sejauh mana kemampuan bank untuk membayar kembali penarikan dana dilakukan oleh deposan dengan mengandalkan kredit yang diberikan sebagai sumber likuiditas. LDR memiliki fungsi untuk mengukur likuiditas bank dengan membagi jumlah kredit yang diberikan oleh bank kepada pihak ketiga. 
$\mathrm{H}_{2}$ : Loan to Deposit Ratio (LDR) berpengaruh terhadap financial distress perusahaan perbankan.

\section{Pengaruh Return on Asset terhadap Financial Distress}

Return On Asset digunakan untuk mengukur kemampuan manajemen bank dalam memperoleh laba secara keseluruhan. Dalam pengukuran Return On Asset, aset yang dimiliki bank digunakan untuk menghasilkan laba kotor (SE BI No 12/10 / DPNP tanggal 31 Maret 2004).

$\mathrm{H}_{3} \quad$ : Return on Asset (ROA) berpengaruh terhadap financial distress perusahaan perbankan

\section{Pengaruh Capital Adequacy Ratio terhadap Financial Distress}

Capital Adequacy Ratio (CAR) merupakan rasio kinerja bank yang digunakan untuk mengukur kecukupan modal yang dimiliki bank untuk menunjang aset yang mengandung atau menghasilkan risko. Rasio ini merupakan faktor penting bagi bank dalam rangka pengembangan usaha dan menampung kerugian. Capital Adequacy Ratio mencerminkan kesehatan bank yang bertujuan untuk menjaga kepercayaan masyarakat terhadap dan melindungi dana masyarakat.

$\mathrm{H}_{4}$ : Capital Adequacy Ratio (CAR) berpengaruh terhadap financial distress perusahaan perbankan

\section{Pengaruh Good Corporate Governance terhadap Financial Distress}

Good Corporate Governance (GCG) merupakan suatu tata kelola bank yang menerapkan prinsip - prinsip keterbukaan, akuntabilitas, pertanggungjawaban, independensi, dan kewajaran yang bertujuan untuk meningkatkan kualitas manajemen dan operasional bank dalam rangka mencari keuntungan. Penyebab perusahaan sukses atau gagal salah satunya adalah karena strategi yang diterapkan di perusahaan, dan GCG merupakan bagian dari penerapan strategi tersebut.

$\mathrm{H}_{5}$ : Good Corporate Governance (GCG) berpengaruh terhadap kondisi Financial Distress.

\section{METODE PENELITIAN}

Jenis penelitian yang digunakan dalam penelitian ini adalah penelitian asosiatif kausal dengan pendekatan kuantitatif. Menurut Sugiyono (2018:37) Penelitian asosiatif merupakan penelitian yang bertujuan mengetahui hubungan antara dua variabel atau lebih, dimana penelitian yang dilakukan bertujuan untuk memperhitungkan kinerja keuangan yang merupakan rasio keuangan dan good corporate governance yang mempengaruhi kondisi kesulitan keuangan bank yang terdaftar di BEI. Penelitian ini menggunakan data yang berasal dari website Bursa Efek Indonesia (BEI) dengan situs www.idx.co.id dan website masing-masing bank tersebut. Periode penelitian yang digunakan adalah tahun 2016-2018. Populasi yang digunakan dalam penelitian ini adalah perusahaan perbankan konvensional yang terdaftar di Bursa Efek Indonesia (BEI) periode 2016-2018. Metode pengambilan sampel dalam penelitian ini adalah metode purposive sampling dengan jumlah total adalah 41 perusahaan perbankan. Dengan observasi selama 3 tahun yaitu 2016-2018 maka diperoleh jumlah observasi sebanyak 123 observasi.

Jenis data yang digunakan dalam penelitian ini adalah data sekunder dan merupakan data kuantitatif dari laporan keuangan periode dan laporan pelaksanaan GCG berupa nilai komposit Self Assessment tahun 2016-2018 yang bersumber dan dipublikasikan di website resmi Bursa Efek Indonesia (www.idx.co.id) dan melalui website resmi masing-masing perbankan tersebut. Variabel independen dalam penelitian ini adalah kinerja keuangan dan good corporate governance, yang dimana untuk variabel 


\section{Risinace}

Vol. 1 No. 4 Desember 2021

kinerja keuangan diproksikan dengan Non performing loan, Loan to Deposit Ratio, Return on Asset, dan Capital Adequacy Ratio sedangkan untuk variabel good corporate governance diproksikan dengan melihat hasil Self Assessment masingmasing perbankan. Variabel dependen dalam penelitian ini adalah Financial Distress yang diukur dengan model Altman's Z-score.

Prosedur analisis data dalam penelitian ini menggunakan regresi linier berganda, setelah sebelumnya dilakukan pengujian asumsi klasik. Analisis regresi linier berganda digunakan dalam penelitian ini untuk menguji pengaruh variabel independen kinerja keuangan dan good corporate governance terhadap variabel dependen yaitu Financial Distress. Berikut ini adalah model persamaan matematis yang diuji :

$\varepsilon$

$\mathrm{Y}=$ Financial Distress

$\mathrm{X} 1=$ Non Performing Loan (NPL)

$\mathrm{X} 2=$ Loan to Deposit Ratio $(\mathrm{LDR})$

$\mathrm{X} 3=$ Return On Asset (ROA)

$\mathrm{X} 4=$ Capital Adequacy Ratio (CAR) X5 = Good Corporate Governance (GCG)

$\varepsilon=$ Standar eror

\section{HASIL DAN PEMBAHASAN}

Hasil statistik deskriptif seluruh variabel menggambarkan nilai minimum, maksimum, rata-rata (mean), dan standar deviasi. Variabel independen yang digunakan dalam penelitian ini adalah kinerja keuangan dengan menggunakan rasio keuangan yaitu Non Perfoming Loan, Loan to Deposit Ratio, Return on Asset, dan Capital Adequacy Ratio, serta menggunakan variabel Good Corporate Governance. Sedangkan variabel dependen dalam penelitian ini adalah financial distress yang diukur dengan menggunakan altman z-score. Hasil pengujian statistik deskriptif tersebut dapat dilihat pada tabel 1 berikut ini:

Tabel 1

Hasil Analisis Statistik Deskriptif

\begin{tabular}{llrrrr}
\hline & N & Minimum & \multicolumn{1}{c}{ Maximum } & Mean & \multicolumn{1}{c}{ Std. Deviation } \\
\hline X1_NPL & 123 & .0 & 9.9 & 2.043 & 1.4730 \\
X2_LDR & 123 & 42.0 & 145.3 & 84.598 & 14.5552 \\
X3_ROA & 123 & -11.2 & 5.1 & .894 & 2.4174 \\
X4_CAR & 123 & 10.0 & 66.4 & 21.883 & 7.6050 \\
X5_GCG & 123 & 1.00 & 3.00 & 2.0701 & .49105 \\
Y_ZSCORE & 123 & -.133909114 & 2.980879777 & 1.38314152131 .634004382413 \\
Valid N (listwise) & 123 & & & & \\
\hline
\end{tabular}

Non perfoming loan dengan nilai minimum adalah sebesar 0,0 , nilai maksimum sebesar 9,9, nilai rata-rata sebesar 2,043, dan nilai standar deviasi sebesar 1,4730. Hasil tersebut menunjukkan bahwa besarnya non perfoming loan yang menjadi sampel berkisar antara 0,0 sampai dengan 9,9 dan data yang dimiliki menunjukkan sebaran yang relative kecil, karena nilai standard deviasi lebih kecil dari nilai rata-ratanya. Dengan demikian dapat disimpulkan data pada variabel non perfoming loan memiliki data yang relatif kecil.

Loan to deposit ratio dengan nilai minimum adalah sebesar 42,0, nilai maksimum sebesar 145,3, nilai rata-rata sebesar 84,598, dan nilai standar deviasi sebesar 14,5552. Hasil tersebut menunjukkan bahwa besarnya loan to deposit ratio yang menjadi sampel berkisar antara 42,0 sampai dengan 145,3 dan data yang dimiliki menunjukkan sebaran yang relative kecil, karena nilai standard deviasi lebih kecil dari nilai rata-ratanya. 
Dengan demikian dapat disimpulkan data pada variabel loan to deposit ratio memiliki data yang relatif kecil.

Return on asset dengan nilai minimum adalah sebesar $-11,2$, nilai maksimum sebesar 5,1, nilai rata-rata sebesar 0,894, dan nilai standar deviasi sebesar 2,4174. Hasil tersebut menunjukkan bahwa besarnya return on asset yang menjadi sampel berkisar antara -11,2 sampai dengan 5,1 dan data yang dimiliki menunjukkan sebaran yang relative besar, karena nilai standard deviasi lebih besar dari nilai rata-ratanya. Dengan demikian dapat disimpulkan data pada variabel return on asset memiliki data yang relatif besar.

Capital adequacy ratio dengan nilai minimum adalah sebesar 10,0, nilai maksimum sebesar 66,4, nilai rata-rata sebesar 21,883, dan nilai standar deviasi sebesar 7,6050. Hasil tersebut menunjukkan bahwa besarnya capital adequacy ratio yang menjadi sampel berkisar antara 10,0 sampai dengan 66,4 dan data yang dimiliki menunjukkan sebaran yang relative kecil, karena nilai standard deviasi lebih kecil dari nilai rata-ratanya. Dengan demikian dapat disimpulkan data pada variabel capital adequacy ratio memiliki data yang relatif kecil.

Good corporate governance dengan nilai minimum adalah sebesar 1,0 , nilai maksimum sebesar 3,0, nilai rata-rata sebesar 2,0701, dan nilai standar deviasi sebesar 0,49105 . Hasil tersebut menunjukkan bahwa besarnya good corporate governance yang menjadi sampel berkisar antara 1,0 sampai dengan 3,0 dan data yang dimiliki menunjukkan sebaran yang relative kecil, karena nilai standard deviasi lebih kecil dari nilai rata-ratanya. Dengan demikian dapat disimpulkan data pada variabel good corporate governance memiliki data yang relatif kecil. financial distress dengan nilai minimum adalah sebesar -0.133909114 , nilai maksimum sebesar 2.980879777 , nilai rata-rata sebesar 1.38314152131, dan nilai standar deviasi sebesar 0.634004382413. Hasil tersebut menunjukkan bahwa besarnya financial distress yang menjadi sampel berkisar antara 0.133909114 sampai dengan 2.980879777 dan data yang dimiliki menunjukkan sebaran yang relatif kecil, karena nilai standard deviasi lebih kecil dari nilai rataratanya. Dengan demikian dapat disimpulkan data pada variabel financial distress memiliki data yang relatif kecil.

Sebelum melakukan pengujian regresi linier berganda, telah dilakukan uji asumsi klasik yang terdiri dari uji normalitas, heterokedastisitas, multikolinieritas dan autokorelasi. Hasil pengujian asumsi klasik menunjukkan bahwa semua variabel telah memenuhi persyaratan uji asumsi klasik sehingga dapat dilanjutkan dengan tahapan pengujian selanjutnya. Hasil pengujian regresi linier berganda disajikan pada tabel 2. Uji statistik F merupakan uji model yang menunjukkan apakah semua variabel independen atau bebas yang dimasukkan dalam model mempunyai pengaruh secara bersama-sama terhadap variabel dependen (Ghozali, 2005: 88). Hasil pengujian statistik F menunjukkan bahwa nilai $\mathrm{F}$ hitung sebesar 34,168 dengan probabilitas 0,000 . Karena probabilitas jauh lebih kecil dari 0,05, maka model regresi dapat digunakan untuk memprediksi financial distress atau dapat dikatakan bahwa Non Perfoming Loan, Loan to Deposit Ratio, Return on Asset, dan Capital Adequacy Ratio, dan Good Corporate Governance secara bersamasama berpengaruh terhadap kinerja keuangan yang diproksikan dengan altman z-score.

Koefisien determinasi $\left(\mathrm{R}^{2}\right)$ pada intinya mengukur seberapa jauh kemampuan model dalam menerangkan variasi variabel dependen (Ghozali, 2005: 83). Hasil pengujian koefisien determinasi $\left(\mathrm{R}^{2}\right)$ untuk model pertama menunjukkan bahwa nilai Adjusted $\mathrm{R}^{2}$ nilai Adjusted $R$ Square yang diperoleh adalah 0,576 atau 57\%. Dari nilai tersebut menandakan kemampuan variabel Non Perfoming Loan, Loan to Deposit Ratio, Return on Asset, dan Capital Adequacy Ratio, dan Good Corporate Governance dalam 


\section{Risinace}

Vol. 1 No. 4 Desember 2021

menjelaskan variabel financial distress yang diproksikan dengan altman z-score yaitu sebesar 57\%. Sedangkan sisanya 43\% variasi variabel financial distress dijelaskan oleh faktor lain yang tidak dimasukkan ke dalam model perhitungan. Hal ini membuktikan masih ada variabel-variabel lain yang mempengaruhi financial distress yang diproksikan dengan altman z-score.

Uji parameter individual (uji statistik t) dilakukan untuk menguji pengaruh variabel independen secara parsial atau sendiri. Hasil pengujian signifikan parameter individual (uji statistik t) menunjukkan bahwa nilai signifikansi non perfoming loan lebih kecil dari 0,05 atau 0,019<0,05 maka $\mathrm{H} 0$ ditolak dan $\mathrm{H} 1$ diterima sehingga menunjukkan bahwa variabel non perfoming loan berpengaruh negatif dan signifikan. Nilai signifikansi loan to deposit ratio lebih kecil dari 0,05 atau 0,001 < 0,05 maka $\mathrm{H} 0$ ditolak dan $\mathrm{H} 1$ diterima sehingga menunjukkan bahwa variabel loan to deposit ratio berpengaruh positif dan signifikan. Nilai signifikansi return on asset lebih kecil dari 0,05 atau 0,001<0,05 maka $\mathrm{H} 0$ ditolak dan $\mathrm{H} 1$ diterima sehingga menunjukkan bahwa variabel return on asset berpengaruh positif dan signifikan. Nilai signifikansi capital adequacy ratio lebih kecil dari 0,05 atau $0,000<0,05$ maka $\mathrm{H} 0$ ditolak dan $\mathrm{H} 1$ diterima sehingga menunjukkan bahwa variabel capital adequacy ratio berpengaruh positif dan signifikan. Nilai signifikansi good corporate governance lebih kecil dari 0,05 atau 0,002 <0,05 maka H0 ditolak dan H1 diterima sehingga menunjukkan bahwa variabel good corporate governance berpengaruh negatif dan signifikan.

Tabel 2

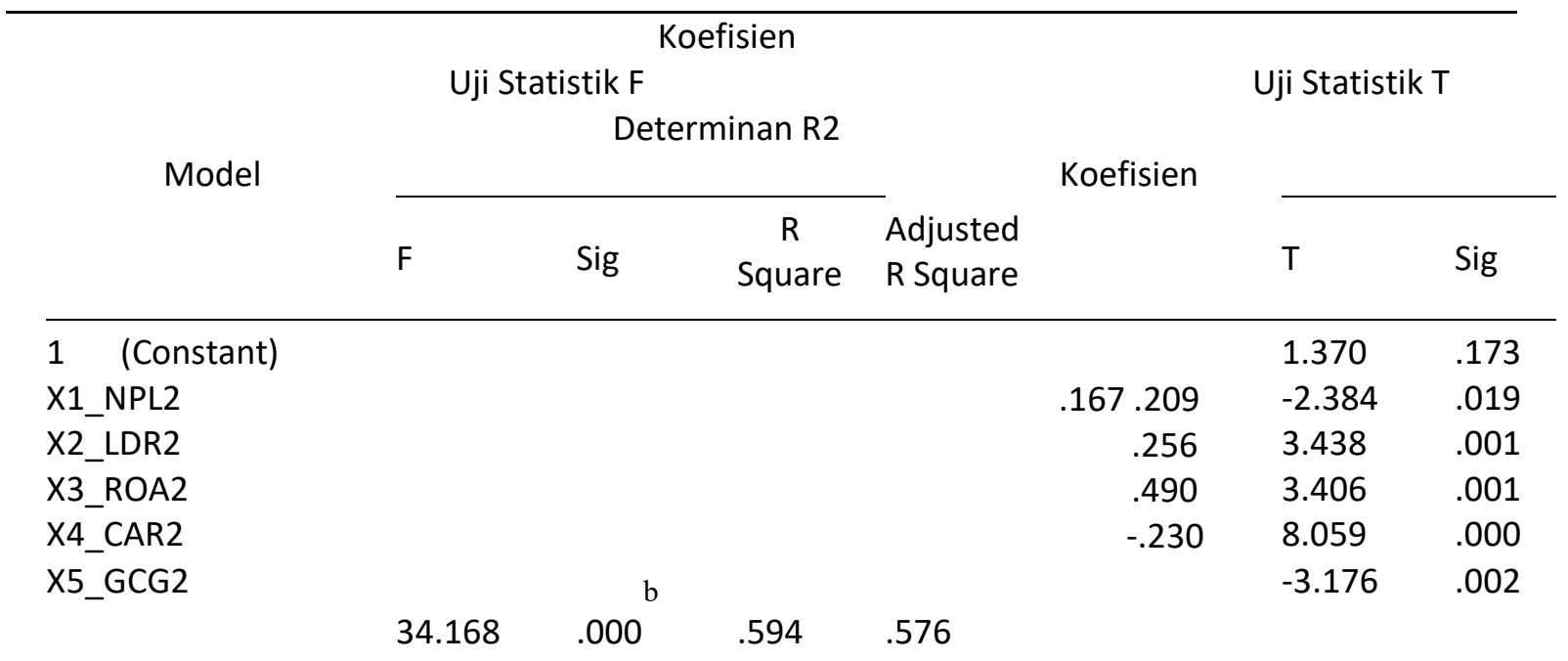

Berdasarkan hasil pengujian hipotesis yang dilakukan pada uji statistik $\mathrm{t}$, dapat dijelaskan bahwa secara parsial Non Perfoming Loan berpengaruh negatif signifikan terhadap financial distress yang diproksikan dengan altman z-score. Hasil penelitian ini tidak sesuai dengan pernyataan yang mengatakan bahwa semakin tinggi Non Perfoming Loan kemungkinan bank mengalami kerugian akan semakin besar. Hal ini akan berdampak pada penurunan pencapaian laba yang mengakibatkan menurunnya profitabilitas. Tingginya Non Perfoming Loan menjadi salah satu penyebab sulitnya bank dalam menyalurkan kredit. Menurut Kasmir (2008) Non Perfoming Loan yang tinggi akan membesar biaya, sehingga berpotensi terhadap jumlah kredit bermasalah semakin besar. Oleh karena itu bank harus menanggung kerugian dalam kegiatan operasionalnya sehingga berpengaruh terhadap penurunan laba yang diperoleh bank 
karena semakin tinggi rasio Non Perfoming Loan maka kredit macet pun semakin tinggi sehingga menghambat bank dalam memperoleh pendapatan dari bunga kredit sehingga financial distress akan meningkat. Hasil analisis menunjukkan Non Perfoming Loan berpengaruh negatif dalam memprediksi probabilitas financial distress karena kredit hanya salah satu aspek dari total aset. Aktiva produktif yang menjadi sumber pendapatan bank banyak ditopang oleh akun-akun lain selain kredit. Selama aktiva produktif bank meningkat maka meningkatnya Non Perfoming Loan akan mengurangi probabilitas financial distress. Hasil ini sesuai dengan penelitian Gebreslassie (2015) yang membuktikan Non Perfoming Loan berpengaruh terhadap financial distress.

Berdasarkan hasil pengujian hipotesis yang dilakukan pada uji statistik $\mathrm{t}$, dapat dijelaskan bahwa secara parsial Loan to Deposit Ratio berpengaruh positif signifikan terhadap financial distress yang diproksikan dengan altman z-score. Hasil ini sesuai dengan pernyataan rasio Loan to Deposit Ratio yang tinggi menunjukkan kemampuan bank untuk mengelola likuiditas yang rendah, yang dapat menyebabkan kemungkinan bank yang mengalami kesulitan keuangan meningkat. Menurut perspektif teori sinyal mengusulkan tentang bagaimana bank seharusnya memberikan sinyal kepada pengguna laporan keuangan, dengan likuiditas perusahaan yang tinggi maka perusahaan memberikan sinyal yang baik kepada pihak eksternal karena bank dalam kondisi baik sehingga meminimalkan keadaan financial distress (S. Kuncoro \& Agustina, 2017). Loan to Deposit Ratio digunakan untuk mengukur besarnya dana yang ditempatkan dalam bentuk kredit yang berasal dari dana yang dikumpulkan oleh bank (dana dari pihak ketiga atau masyarakat). Semakin tinggi tingkat rasio Loan to Deposit Ratio maka semakin tinggi pula potensi bank tersebut mengalami financial distress. Hasil ini sesuai dengan penelitian Gebreslassie (2015) yang membuktikan Loan to Deposit Ratio berpengaruh terhadap financial distress.

Berdasarkan hasil pengujian hipotesis yang dilakukan pada uji statistik t, dapat dijelaskan bahwa secara parsial Return On Asset berpengaruh positif signifikan terhadap financial distress yang diproksikan dengan altman z-score. Hasil penelitian ini tidak sesuai dengan pernyataan yang mengatakan bahwa semakin besar Return On Asset bank, maka semakin besar tingkat keuntungan yang dicapai oleh bank dan semakin baik posisi bank dalam hal penggunaan aset. Semakin tinggi tingkat Return On Asset maka kemungkinan bank mengalami kesulitan keuangan akan lebih kecil. Jika laba perusahaan tinggi, maka perusahaan akan memberikan sinyal kepada pihak internal atau eksternal sebagai sinyal yang baik karena mengidentifikasi kondisi perusahaan juga, sehingga akan meningkatkan nilai perusahaan dan meminimalkan terjadinya financial distress. Hasil ini sesuai penelitian Septiliana, dkk (2018) dan Yurivin (2018) yang membuktikan Return On Asset berpengaruh positif terhadap financial distress.

Berdasarkan hasil pengujian hipotesis yang dilakukan pada uji statistik t, dapat dijelaskan bahwa secara parsial Capital Adequacy Ratio berpengaruh positif signifikan terhadap financial distress yang diproksikan dengan altman z-score. Hasil penelitian ini tidak sesuai dengan pernyataan yang mengatakan bahwa semakin tinggi Capital Adequacy Ratio maka kinerja suatu bank juga semakin tinggi. Dimana total aset akan meningkat sehingga financial distress akan menurun. Capital Adequacy Ratio merupakan rasio kinerja bank yang digunakan untuk mengukur kecukupan modal yang dimiliki bank untuk menunjang aset yang mengandung atau menghasilkan risko. Rasio ini merupakan faktor penting bagi bank dalam rangka pengembangan usaha dan menampung kerugian. Capital Adequacy Ratio mencerminkan kesehatan bank yang bertujuan untuk menjaga kepercayaan masyarakat terhadap dan melindungi dana masyarakat. Capital Adequacy 


\section{Risinace}

Vol. 1 No. 4 Desember 2021

Ratio menunjukkan sejauh mana penurunan aset bank masih dapat ditutupi oleh ekuitas bank yang tersedia. Peningkatan rasio Capital Adequacy Ratio menandakan peningkatan kesehatan bank, sehingga akan menurunkan risiko kesulitan keuangan karena modal tinggi menunjukkan kredit yang rendah. Semakin tinggi tingkat modal, semakin tinggi cadangan kas sehingga bank dapat menyalurkan lebih banyak kredit dan pada akhirnya menghasilkan laba yang besar. Dampaknya adalah bank akan memberikan sinyal yang baik kepada pihak eksternal bahwa perusahaan bank dalam kondisi baik. Investor percaya dan menginvestasikan modalnya di bank. Ini membuat perusahaan mendapatkan modal untuk menjalankan bisnisnya dan menghindari kesulitan keuangan (S. Kuncoro \& Agustina, 2017). Hasil ini sesuai penelitian Pratama (2016) yang membuktikan Capital Adequacy Ratio berpengaruh positif terhadap financial distress.

Berdasarkan hasil pengujian hipotesis yang dilakukan pada uji statistik $\mathrm{t}$, dapat dijelaskan bahwa secara parsial Good Corporate Governance berpengaruh negatif signifikan terhadap financial distress yang diproksikan dengan altman z-score. Hasil penelitian ini tidak sesuai dengan pernyataan yang mengatakan bahwa semakin besar Good Corporate Governance yang dinilai dengan nilai komposit suatu bank, maka semakin besar kemungkinan bank mengalami kesulitan keuangan. Good Corporate Governance merupakan suatu tata kelola bank yang menerapkan 11 aspek penilaiam yang kemudian akan diberikan peringkat dari 1 sampai 5. Hasil penilaian self assessment tersebut jika mendapatkan peringkat 1 maka tata kelola perusahaan perbankan dikatakan sangat baik dan jika mendapatkan peringkat 5 dikatakan sangat buruk. Perusahaan yang memiliki tata kelola dan manajemen yang baik akan memberikan lebih banyak sinyal kepada pihak internal dan eksternal agar tidak terjadinya informasi asimetri, seperti agar investor tidak salah dalam memilih saham untuk berinvestasi. Semakin baik penerapan mekanisme corporate governance, bank akan berada dalam kondisi pemantauan yang baik, sehingga akan meningkatkan kinerja bank yang bersangkutan dan mengurangi kondisi financial distress di suatu perusahaan (S. Kuncoro \& Agustina, 2017). Hasil ini sesuai dengan penelitian S. Kuncoro \& Agustina (2017) yang membuktikan bahwa good corporate governance berpengaruh negatif terhadap financial distress.

\section{KESIMPULAN, KETERBATASAN, DAN SARAN}

Penelitian ini bertujuan untuk menguji pengaruh kinerja keuangan dan good corporate governance terhadap financial distress. Hasil pengujian penelitian menunjukkan bahwa kinerja keuangan yang diproksikan dengan loan to deposit ratio, return on asset, dan capital adequacy ratio berpengaruh positif terhadap financial distress yang diproksikan dengan altman z-score. Sedangkan kinerja keuangan yang diproksikan dengan non perfoming loan dan good corporate governance yang diukur dengan self assessment GCG berpengaruh negatif terhadap financial distress yang diproksikan dengan altman z-score. Hal ini menunjukkan bahwa kredit hanya salah satu aspek dari total aset. Aktiva produktif yang menjadi sumber pendapatan bank banyak ditopang oleh akun-akun lain selain kredit. Selain itu, hal ini menunjukkan semakin tinggi nilai good corporate governance kinerja bank yang bersangkutan dikatakan sedang tidak baik dan menambah kondisi financial distress di suatu perusahaan.

Pada penelitian ini periode pengamatan selama tiga tahun yaitu 2016-2018 sehingga memiliki rentan waktu observasi yang relatif pendek. Jadi penelitian mendatang dapat memperpanjang periode pengamatan supaya sampel yang digunakan lebih banyak menjadi minimal lima tahun. Hal ini dimaksudkan agar kesimpulan yang dihasilkan dari penelitian tersebut memiliki cakupan yang lebih luas. 
Variabel independen dalam penelitian ini hanya bisa menjelaskan variabel dependen sebesar 57\% dan sisanya 43\% terdapat pada variabel lain yang tidak digunakan dalam penelitian ini. Hasil ini mengindikasi bahwa variabel independen tersebut belum dapat sepenuhnya mempengaruhi financial distress. Sehingga pada penelitian selanjutnya diharapkan dapat menambah variabel independen seperti BOPO (Biaya Operasional terhadap Pendapatan Operasional) dan NIM (Net Interest Margin) agar hasil yang didapatkan lebih kuat dan akurat.

\section{REFERENSI}

Africa, L. A. (2018). Bankometer Models For Predicting Financial Distress I Banking Industry. Jurnal Keuangan Dan Perbankan, 22(2), 373-379.

Afriyeni, E. (2012). Model Prediksi Financial Distress Perusahaan. Polibisnis, 4 (2), h: $1-10$.

Almilia, LS. (2006). Prediksi Kondisi Financial Distress Perusahaan Go Public Dengan Menggunakan Analisis Multinominal Logit. Jurnal Ekonomi dan Bisnis. Vol.7 No.1.

Altman, E. I. (1969). Financial ratios, discriminant analysis and the prediction of corporate bankruptcy. The journal of finance, 23(4), 589-609.

Andari, Ni Made Meliana Dan Wiksuana, I Gusti Bagus (2017). RGEC Sebagai Determinasi Dalam Menanggulangi Financial Distress Pada Perusahaan Perbankan Di Bursa Efek Indonesia. E-Jurnal Manajemen Unud. Vol.6 No.1, 116-145.Universitas Udayana.

Choirina, Putri Mutia. (2015). Analisis Faktor-Faktor Yang Mempengaruhi Probabilitas Financial Distress Perbankan Indonesia. Skripsi. Universitas Diponegoro.

Daniri, A. (2005). Good Corporate Governance, Konsep Dan Penerapannya Dalam Konteks Indonesia. Jakarta: PT Ray Indonesia.

Defrio, M., \& Meiranto, W. (2013). Analisis Faktor-Faktor Pembentuk Kinerja (CAMELS) Pada Perbankan Indonesia (Studi Kasus Pada Bank Yang Terdaftar Di BEI). Diponegoro Journal Of Accounting, 2(November 1997), 42.

Elloumi, Fathi dan Jean-Pierre Gueyie. "Financial Distress and Corporate Governance: An Empirical Analysis”, MCB University Press. 2001, vol.1 no.1, hal. 15-23.

Gebreslassie, E. (2015). Determinants Of Financial Distress Conditions Of Commercial Banks In Ethiopia : A Case Study Of Selected Private Commercial Banks. Journal Of Poverty, Investment And Development, 13, 59-74.

Ghozali, Imam. 2018. Aplikasi Analisis Multivariate dengan Program IBM SPSS 25. Edisi 9. Semarang: Badan Penerbit Universitas Diponegoro.

Gumanti, Tatang Ari, 2009. Teori Sinyal Dalam Manajemen Keuangan. (Online). (http://www.researchgate.net/publicati on/265652260). Diakses 10 Februari 2020.

Hadi, Selfi A. F. (2015). Mekanisme Corporate Governance dan Kinerja Keuangan Pada Perusahaan yang Mengalami Financial Distress. Jurnal Ilmu \& Riset Akuntansi. $3(5), 1-17$.

Harahap, Safitri Hanifa. (2015). Pengaruh Rasio CAMEL Dan Corporate Governance Terhadap Financial Distress Pada Perusahaan Perbankan Yang Terdaftar Di Bursa Efek Indonesia Periode 2009-2013. S1 thesis. Universitas Negeri Jakarta.

Hasibuan, Nirmala Sari. (2013). Analisis Rasio Keuangan Untuk Memprediksi Financial Distress Perusahaan Perbankan yang Terdaftar di Bursa Efek Indonesia Tahun 2008-2011. STIE Perbanas Surabaya. 


\section{Risinawe}

Vol. 1 No. 4 Desember 2021

Hery. (2015). Analisis Laporan Keuangan: Pendekatan Rasio Keuangan.Yogyakarta. Hidayati, Lina Nur. (2015). Pengaruh Kecukupan Modal (CAR), Pengelolaan Kredit (NPL), dan Likuiditas Bank (LDR) Terhadap Probabilitas Kebangkrutan Bank (Studi Pada Bank

Umum Swasta Devisa Yang Tercatat di BEI Tahun 2009-2013). Jurnal Ilmu Manajemen. $12(1), 38-50$.

Iflaha, D.A. (2008). Analisis Financial Distress Dengan Metode Z-Score Untuk Memprediksi Kebangkrutan Perusahaan (Studi Pada Perusahaan Restoran, Hotel dan Pariwisata yang Listing di Bursa Efek Indonesia Periode 2003-2007). Skripsi. Fakultas Ekonomi. Universitas IslamNegeri. Malang.

Ismawati, Kun Dan Istria, Paula Chrisna. (2015). Detektor Financial Distress Perusahaan Perbankan Indonesia. Ekonomi Bisnis dan Kewirausahaan. Vol. IV No. 1. Universitas Surakarta.

Kasmir. (2008). Pemasaran Bank. Jakarta: PT Raja Grafindo Persada.

Kuncoro, S., \& Agustina, L. (2017). Factors To Predict The Financial Distress Condition Of The Banking Listed In The Indonesia Stock Exchange. Accounting Analysus Journal, 6(1), 39-47.

Kurniasari, Christiana dan Ghozali, Imam. (2013). Analisis Pengaruh Rasio CAMEL Dalam Memprediksi Financial Distress Perbankan Indonesia. Skripsi. Fakultas Ekonomika dan Bisnis Universitas Diponegoro.

Maisarah, Zamzami, \& Diah, E. (2018). Analisis Rasio Keuangan Untuk Memprediksi Kondisi Financial Distress Perbankan Syariah Di Indonesia (Studi Kasus Pada Bank Syariah Di Indonesia Periode 2011-2016). Jurnal Akuntansi Dan Keuangan Universitas Jambi, 74(4), 157-162.

Mayangsari, L. P., \& Andayani. (2015). Pengaruh Good Corporate Governance Dan Kinerja Keuangan Terhadap Financial Distress. Jurnal Ilmu \& Riset Akuntansi, 4(4), 1-18.

Nuranto, Ayang Aulia dan Ardiansari, Anindya. (2017). Pengaruh Rasio Keuangan, Firm Size, dan Market Effect terhadap Tingkat Kebangkrutan. Management Analysis Journal. 6 (2), 183-194.

Peraturan BI No. 13/1/PBI/2011

Prasetyo, Eka Adhi dan Demi, Irine Rini. (2011). Faktor-Faktor yang Mempengaruhi Kondisi Financial Distress Perusahaan Perbankan yang Listing di BEI Tahun 2006-2008. Universitas Diponegoro.

Pratama, Rendra. (2016). Analisis Pengaruh Rasio Keuangan Untuk Memprediksi Kondisi Financial Distress Bank Umum Syariah Menggunakan Model Logit di Indonesia. STIE Perbanas Surabaya.

Rahmawati, Diah Dan Khoiruddin, Moh. (2017). Pengaruh Corporate Governance dan Kinerja Keuangan Dalam Memprediksi Kondisi Financial Distress. Management Analysis Journal. Universitas Negeri Semarang.

Sastriana, Dian. (2013). Pengaruh Corporate Governance Dan Firm Size Terhadap Perusahaan Yang Mengalami Kesulitan Keuangan (Financial Dostress). Skripsi. Universitas Diponegoro.

Sadida, B. D. (2016). Risk Profile, Good Corporate Governance, Earnings, And Capital (RGEC) Sebagai Prediktor Terhadap Kondisi Financial Distress Pada Perusahaan Perbankan Risk Profile, Good Corporate Governance, Earnings , And Capital (RGEC) As The Predictors Towards. Jurnal Manajemen Bisnis Indonesia, 4(1), 347-357. 
Septiliana, Deby, Ruwanti, Sri dan Sofia, Myrna. (2018). Pengaruh Return on Assets (ROA), Current Ratio (CR), Total Assets Turnover (TATO), Return on Equity (ROE), dan Debt Ratio (DR) Dalam Memprediksi Financial Distress Perusahaan Manufaktur Sektor Industri Dasar dan Kimia Yang Terdaftar di BEI Periode 2012-2015. Universitas Maritim Raja Ali Haji.

Siregar, Rizky Indriyani dan Fauzie, Syarief. (2014). Analisis Manfaat Rasio Keuangan Dalam Memprediksi Financial Distress Pada Perbankan (2007-2012). Ekonomi dan Keuangan, 2 (12)

Situs Bursa Efek Indonesia (www.idx.co.id)

Situs Edu Saham (www.edusaham.com)

Spence, M. (1973). Job Market Signaling. The Quarterly Journal of Economics, Vol. 87, No. 3, 355-374.

Sugiyono. 2015. Metode Penelitian dan Pengembangan (Research and Development / $R \& D)$. Bandung: Alfabeta.

Sugiyono. 2018. Metode Penelitian : Kuantitatif, Kualitatif, dan R\&D. Bandung: Alfabeta.

Sumantri dan Jurnali, Teddy. (2010). Manfaat Rasio Keuangan Dalam Memprediksi Kepailitan Bank Nasional. Jurnal Bisnis dan Akuntansi. Vol. 12, No. 1 : 39-52. Universitas Internasional Batam.

Supardi dan Sri Mastuti. (2003). Validitas Penggunaan Z-Score Altman untuk Menilai Kebangkrutan Pada Perusahaan Perbankan Go Public di Bursa Efek Jakarta. Jakarta: Kompak.

SE BI No 12/10 / DPNP tanggal 31 Maret 2004

Surat Edaran Bank Indonesia No.15/15/DPNP Tahun 2013

Surat Edaran OJK(SEOJK) No.13/SEOJK.03/2017

Syaryadi, Fikri. (2012). Pengaruh Likuiditas Terhadap Financial Distress Perusahaan Industri Tekstil dan Garmen yang Terdaftar di Bursa Efek Indonesia. digilib.polsri.ac.id.

Triasdini, H. 2010. Pengaruh CAR, NPL dan ROA terhadap Penyaluran Kredit Modal Kerja (Studi pada Bank Umum yang Terdaftar di BEI 2004-2009). Skripsi, Program Sarjana (S1) Universitas Diponegoro. Semarang.

Tuanakotta, Theodorus, M. (2010). Akuntansi Forensik dan Audit Investigasi. Jakarta: Departemen Akuntansi Universitas Indonesia.

Uli AY. 2009. Analisis Pengaruh Faktor Fundamental dan Risiko Sistematik Terhadap Harga Saham Pada Perusahaan Sektor Industri Barang Konsumsi di BEI. Jakarta (ID): Jurnal Jurusan Akuntansi Universitas Gunadarma.

UU Nomor 10 Tahun 1998

Wandari, Sillvi Ayu. (2017). Pengaruh Kualitas GCG, ROA Dan Leverage Terhadap Financial Distress Pada Perusahaan Yang Terdaftar Di BEI Periode 2011-2015. Journal of Social and Economics Research. Vol. 2. STIE Perbankan Indonesia.

Widiastuty, Tri. (2018). Penilaian GCG dan Size Serta Pengaruhnya terhadap Financial Distress Menggunakan Bankometer. ISEI Accounting Review. 2 (2), 26-33.

Wongsosudono, Corina \& Chrissa (2013). Analisis Rasio Keuangan Untuk Memprediksi Financial Distress Pada Perusahaan Sektor Keuangan Yang Terdaftar Di Bursa Efek Indonesia. Jurnal Akuntansi IBBI.

Yurivin, Nerissa. (2018). Analisis Faktor-Faktor Yang Mempengaruhi Financial Distress Pada Perusahaan Perbankan di Indonesia (Studi Pada Bank Umum Swasta Devisa dan Non Devisa Periode 2012-2016). Skripsi. Universitas Diponegoro. 